\title{
Contrasting serpentinization processes in the eastern Central Alps
}

\author{
Dorothee J.M. Burkhard * and James R. O'Neil ** \\ Mineralogical and Petrological Institute, University of Heidelberg, D-6900 Heidelberg, Federal Republic of Germany \\ US Geological Survey, Menlo Park, CA 94025, USA
}

\begin{abstract}
Stable isotope compositions have been determined for serpentinites from between Davos (Arosa-Platta nappe, Switzerland) and the Valmalenco (Italy). $\delta D$ and $\delta^{18} O$ values $(-120$ to -60 and $6-10 \%$, respectively) in the Arosa-Platta nappe indicate that serpentinization took place on the continent at relatively low temperatures in the presence of limited amounts of metamorphic fluids that contained a component of meteoric water. One sample of chrysotile has a $\delta^{18} O$ value of $13 \%$ providing evidence of high $W / R$ ratios and low formation temperature of lizarditechrysotile in this area. In contrast, relatively high $\delta D$ values $\left(-42\right.$ to $-34 \%$ ) and low $\delta^{18} O$ values $(4.4-7.4 \%$ ) for serpentine in the eastern part of the Valmalenco suggest a serpentinization process that took place at moderate temperatures in fluids that were dominated by ocean water. The antigorite in the Valmalenco is the first reported example of continental antigorite with an ocean water signature. An amphibole sample from a metasomatically overprinted contact zone to metasediments $(\delta D=-36 \%)$ indicates that the metasomatic event also took place in the presence of ocean water. Lower $\delta D$ values ( -93 to $-60 \%$ ) of serpentines in the western part of the Valmalenco suggest a different alteration history possibly influenced by fluids associated with contact metamorphism. Low water/rock ratios during regional metamorphism (and metasomatism) have to be assumed for both regions.
\end{abstract}

\section{Introduction}

Ultramafic rocks are usually serpentinized. The character and extent of the serpentinization process depends on a number of factors including whether the alteration occurred at constant volume or isochemically, the source of the water, the temperature, and the fluid/rock ratio. These factors are reflected by the hydrogen and oxygen isotope compositions of the serpentine minerals. Variations in the hydrogen and oxygen isotope compositions and the serpentinizing fluids have been investigated by Barnes and O'Neill (1969), Wenner and Taylor (1969, 1971, 1973, 1974), Margaritz and Taylor (1974), Heaton and Sheppard (1977), Ikin

Present address: *Department of Geology, University of Melbourne, Parkville, Victoria 3052, Australia. ** Department of Geological Sciences, University of Michigan, Ann Arbor, MI 48109-1063, USA

Offprint requests to: D.J.M. Burkhard and Harmon (1983), and Yui and Yeh (1986). Major conclusions inferred from these data are: (1) formation of continental lizardite-chrysotile took place on the continent at relatively low temperatures (often less than $150^{\circ} \mathrm{C}$ and possibly as low as surface temperatures, Barnes and O'Neill 1969 ) in the presence of low- $T$ alteration-fluids that contain varying proportions of meteoric water, (2) most oceanic serpentines (dredged from the ocean floor) with characteristically high $\delta D$ values $\left(-35\right.$ to $-68 \%$ ) and low $\delta^{18} O$ values $(0.8-6.7 \%$ ) formed at moderate temperatures $\left(350 \pm 50^{\circ} \mathrm{C}\right)$ in the presence of a fluid dominated by ocean water, and (3) ophiolitic serpentines do not bear the isotopic composition typical of oceanic serpentines and may have formed after uplift under low temperature continental conditions.

If continental serpentinization were to occur at near surface temperatures, we should expect to observe minerals with relatively high $\delta^{18} O$ values (around $12-15 \%$ or higher depending on the isotopic composition of the surface water) because the magnitude of the isotopic fractionation factors are large at low temperatures. However, values this high have only rarely been observed in a few samples from ophiolites in Troodos, Cyprus (Margaritz and Taylor 1974) and Vourinos, Greece (Wenner and Taylor 1973), a suite of serpentine-like mineraloids called deweylites (Wenner and Taylor 1974) and a single sample from the present study. The paucity of such data may reflect a sampling bias but could also mean that water/rock ratios are fairly low during most serpentinization processes on the continent and, consequently, that the oxygen isotopic composition of the serpentine is largely inherited from the precursor minerals (Barnes et al. 1978).

In this study the stable isotope geochemistry of ophiolitic serpentinites from the Arosa-Platta nappe in the eastern Central Alps are contrasted with those of serpentines from the nearby Valmalenco region. The results help to more clearly define the nature of serpentinization processes occurring in zones of continental collision.

\section{Geology and mineralogy}

Serpentinized ultramafics in the eastern Central Alps belong to the Pennine nappes and occur along a N-S section of about $60 \mathrm{~km}$ at the boundary to overlying Austroalpine nappes, from the DavosArosa region, Switzerland, to the Valmalenco, Italy (Fig. 1).

The northern occurrences of serpentinite (Arosa-Platta nappe between Davos and the Engadin) are ultramafic tectonites of a dissected ophiolite remnant which include associated tholeiitic 


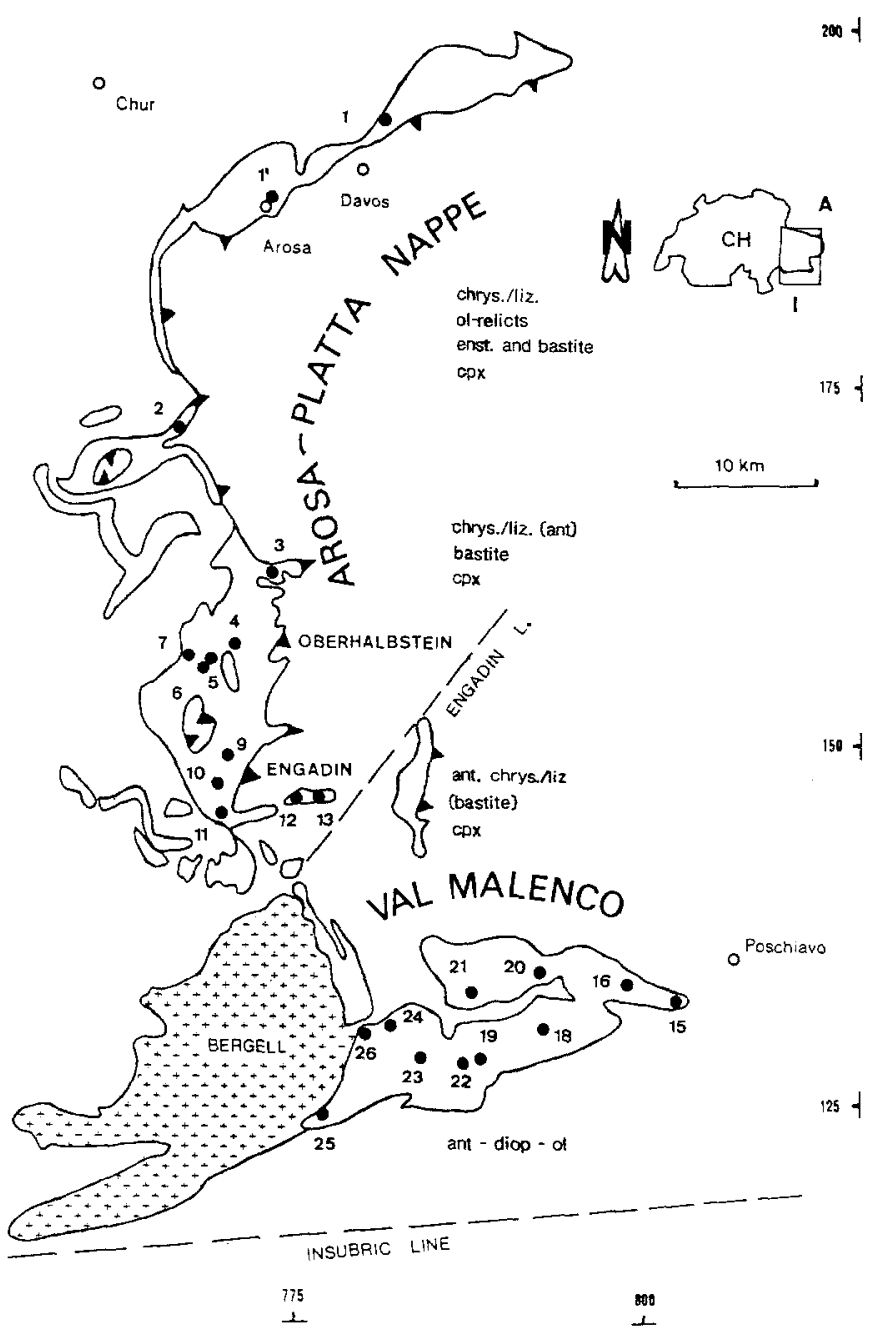

Fig. 1. Tectonic sketch map with the ophiolites of the Arosa-Platta nappe and the Val Malenco ultramafic complex and the main silicate assemblages in the serpentinites. The sampling localities for stable isotope analyses are: Arosa-Platta nappe: 1: Davos (Da); 1': Arosa; 2: Tgant Ladrung (OH1); 3: Tinzener Ochsenalp (OH4); 4: Gruba (OH5); 7: Muttans (OH11); 9: Schlucht Bivio (SchB); 10: Sur al Cant Fuorcla (SCF, OSCF); 11: Lunghin Area (Lungh); 12: Blaunca (Bl); 13: Grevasalvas (Grev); Valmalenco: 15: Selva; 16: Pass d'Ur (P. d'Ur); 18: Franscia (Fr.); 19: Chiesa; 20: Nero; 21: Alpe Senevedo (VM6); 22: above Chiesa (Prim); 23: Laghetti di Sassersa (Lagh); 4: Val Ventina (Vent); 25: Val Masino, Preda Rossa (V. Mas); 26: Val Sissone, (V. Siss)

meta-basalts and meta-sediments (radiolarites, cherts etc.) of Upper Jurassic to Upper Cretaceous age (Peters 1963; Dietrich 1967, $1969,1970,1979$ ). A progressive alpine (regional) metamorphism correlates with the degree of serpentinization: in the prehnite-pumpellyite facies (Davos-Arosa) chrysotile/lizardite (chrys/liz) occurs with some relict olivine. Orthopyroxene (opx) can be unaltered or serpentinized in the north. With increasing grade of metamorphism to the south, ol and opx are serpentinized. Chrys/liz predominate up to the middle of the Oberhalbstein, and antigorite is the most abundant mineral with the transition to the greenschist facies. Cpx occurs fresh or exsolved with opx lamellae throughout the entire Arosa-Platta nappe (Burkhard 1987).

The Valmalenco ultramafic rocks occupy an area of about $180 \mathrm{~km}^{2}$. The typical metamorphic association is antigorite-olivinediopside; antigorite is the only serpentine mineral, besides submicroscopic occurrences of chrysotile discovered by Mellini et al. (1987). Olivine is in most cases recrystallized and the pyroxene is pure diopside. Some of it contains exsolved chlorite lamellae of a former high-Al component. Bucher and Pfeiffer (1973) suggested that the ultramafic complex may be of pre-Mesozoic age because it has a pre-alpine foliation and contains more than one generation of metamorphic minerals. During late Tertiary time the serpentinite complex was intruded by the Bergell granodiorite (Bregaglia Intrusion) in the western part of the Valmalenco which caused a contact metamorphic overprint to the amphibolite ( \pm granulite) facies (Trommsdorff and Evans 1972, 1977; Gautschi and Montrasio 1978; Burkhard 1987).

Al-spinel is common in the Davos region whereas two spinels, an Al-Cr- and a Cr-spinel occur in the Oberhalbstein and the Engadin. In the east Valmalenco, the original Cr-spinel is altered and recrystallized to a $\mathrm{Cr}$-bearing magnetite, whereas the $\mathrm{Cr}$ content of relict centers occasionally exceeds $30 \mathrm{wt} . \%$ in the west Valmalenco. An irregular and a high content of $\mathrm{TiO}_{2}$ is characteristic of all Valmalenco spinels (Burkhard 1987; Burkhard and Amstutz 1988).

Small massive $\mathrm{Fe}-\mathrm{Cu}(-\mathrm{Ni})$ sulfide deposits are generally located at the boundary to the Austroalpine nappe units in the Oberhalbstein and the Engadin (Dietrich 1972). They are in the serpentinite body and not related to tectonic elements in the Valmalenco (De Capitani et al. 1981). Detailed descriptions and discussion of these sulfide occurrences and accessory opaque phases are given in Burkhard (1987).

\section{Analytical procedures}

Only fresh and unaltered serpentine minerals were selected for stable isotope analysis and the parent rocks were normally well serpentinized. The samples were ground with a mortar and pestle, washed with $\mathrm{HCl}$ to remove carbonate, and the magnetite was removed with a hand magnet. The purity of the final separates was usually better than $98 \%$.

The mineral separates were pumped in vacuum at $150^{\circ} \mathrm{C}$ for several hours and then heated to $1400^{\circ} \mathrm{C}$ to quantitatively liberate water. Any $\mathrm{H}_{2}$ produced during this procedure was converted to $\mathrm{H}_{2} \mathrm{O}$ by oxidation over a $\mathrm{CuO}$ furnace. The water was then reacted with $\mathrm{Zn}$ at $450^{\circ} \mathrm{C}$ to produce $\mathrm{H}_{2}$ for isotopic analysis. Oxygen was liberated from the minerals by reaction with $\mathrm{ClF}_{3}$ at $550^{\circ} \mathrm{C}$ and converted over a heated graphite rod to produce $\mathrm{CO}_{2}$ for isotopic analysis. The isotopic ratios were determined on conventional isotope ratio mass spectrometers. The data are reported in the familiar $\delta$-notation in \%o relative to the SMOW standard. The precision of the $\delta^{18} O$ and $\delta D$ values are better than \pm 0.2 and $\pm 1 \%$ respectively.

\section{Results}

The isotopic analyses and sample locations are given in Tables 1 and 2 and the isotopic data $\delta D$ and $\delta^{18} O$ are plotted in Fig. 2. Figures 3 and 4 show the N-S and E-W distribution of $\delta^{18} O$ for the Arosa-Platta nappe and the Valmalenco, respectively, and in Fig. $5 \delta D$ values are plotted on a sketch map of the area. The data for the samples from the Arosa-Platta nappe correspond to the field observed by Wenner and Taylor $(1973,1974)$ for continental alpine type chrys/liz. The antigorites in the east Valmalenco region have $\delta D$ and $\delta^{18} O$ values of around $-40 \%$ and 4 to $7 \%$, respectively. Such values are typical for serpentine and amphibole which formed in fluids with a dominant component of ocean water (e.g. Wenner and Taylor 1973; Heaton and Sheppard 1977; Stakes and O'Neil 1982; Smith et al. 1984). The Valmalenco serpentines are the first reported examples of antigorites with an ocean water signature that are found on the continent. It is noteworthy that, to date, only one stable isotope analysis has been reported for antigorite collected from the ocean floor, and this is a picrolite variety (Wenner and Taylor 1973). In the west Valmalenco the 
Table 1. Stable isotope compositions of serpentinites in the Arosa-Platta nappe

\begin{tabular}{|c|c|c|c|c|c|}
\hline Sample field \# & $\begin{array}{l}\text { Region } \\
\text { Arosa-Platta nappe }\end{array}$ & Swiss Coordinates & Sample description & $\delta D$ & $\delta^{18} D$ \\
\hline Da 7 & Davos, Totalpserp. & $780.34 / 189.74$ & $\mathrm{C} / \mathrm{L}, \mathrm{cpx},(\mathrm{opx})$ & -134 & 7.0 \\
\hline Da 8 & Davos, Totalpserp. & $780.38 / 189.82$ & $\mathrm{C} / \mathrm{L}, \mathrm{B}, \mathrm{cpx}$, massive & -119 & 6.7 \\
\hline Da 9 & Davos, Totalpserp. & $780.39 / 189.85$ & $C / L, c p x,(o p x)$ & -126 & 6.8 \\
\hline Da 11 & Davos, Totalpserp. & $780.94 / 189.23$ & $\mathrm{C} / \mathrm{L}, \mathrm{cpx},(\mathrm{opx})$ & -116 & 6.8 \\
\hline Da 17 & Davos, Totalpserp. & $781.00 / 190.43$ & $\mathrm{C} / \mathrm{L}$ & -104 & 9.8 \\
\hline DaDrus 1 & Davos & & $\mathrm{C} / \mathrm{L}, \mathrm{B}$ & -120 & 7.8 \\
\hline Arosa 1 & Arosa & $770.14 / 184.76$ & $\mathrm{C} / \mathrm{L}, \mathrm{cpx},(\mathrm{opx})$ & -125 & 6.7 \\
\hline Arosa 4 & Arosa & $768.05 / 184.75$ & $\mathrm{C} / \mathrm{L}$ & -95 & 10.6 \\
\hline $\mathrm{OH} 1 / 4$ & N-Oberhalbstein & $746.55 / 168.27$ & $\mathrm{C} / \mathrm{L}$, sulf & -60 & 10.0 \\
\hline $\mathrm{OH} 1 / 9$ & N-Oberhalbstein & $746.55 / 168.27$ & $\mathrm{C} / \mathrm{L}, \mathrm{B}$, later veins, (carb) & -62 & 13.0 \\
\hline $\mathrm{OH} 4 / 1$ & N-Oberhalbstein & $771.85 / 159.25$ & $\mathrm{C} / \mathrm{L}, \mathrm{B}$, carb massiv & -62 & 7.8 \\
\hline OH5/11 & Middle Oberhalbst. & $769.20 / 153.79$ & $\mathrm{C} / \mathrm{L} \mathrm{cpx}$, massiv & -69 & 6.9 \\
\hline OH5/12 & Middle Oberhalbst. & $769.20 / 153.79$ & $\mathrm{C} / \mathrm{L}$ ilv, massiv & -58 & 6.1 \\
\hline $\mathrm{OH} 11 / 3$ & Middle Oberhalbst. & $765.93 / 152.76$ & $\mathrm{C} / \mathrm{L}, \mathrm{B}$ & -97 & 7.0 \\
\hline OSCF3 & S-Oberhalbstein & $768.67 / 144.38$ & A, massiv & -69 & 6.0 \\
\hline OSCF4 & S-Oberhalbstein & $768.67 / 144.38$ & $A$, later vein & -103 & 6.4 \\
\hline Lungh 14 & Engadin & $771.00 / 142.42$ & A, cpx, filt-like (carb) & -76 & 6.2 \\
\hline LP & Engadin & $771.56 / 142.34$ & $\mathrm{~A},(\mathrm{chl})$ & -50 & 6.9 \\
\hline LPP & Engadin & $771.32 / 142.34$ & $\mathrm{C} / \mathrm{L}, \mathrm{B},(\mathrm{A})$ & -100 & 7.2 \\
\hline B1. 5 & Engadin & $774.64 / 143.92$ & $\mathrm{~A},(\mathrm{C} / \mathrm{L}),(\mathrm{cpx})$ & -47 & 9.9 \\
\hline B1. 11 & Engadin & $774.50 / 143.70$ & A, later vein sulf. & -60 & 9.6 \\
\hline B1. 12 & Engadin & $774.50 / 143.70$ & $A,(C / L)$, sulf & -66 & 9.6 \\
\hline Grev. 1 & Engadin & $776.12 / 144.32$ & $A,(C / L)$ & -62 & 6.5 \\
\hline Grev. 6 & Engadin & $776.20 / 144.23$ & A, L, (carb) & -70 & 6.2 \\
\hline
\end{tabular}

Table 2. Stable isotope compositions of serpentinites in the Valmalenco

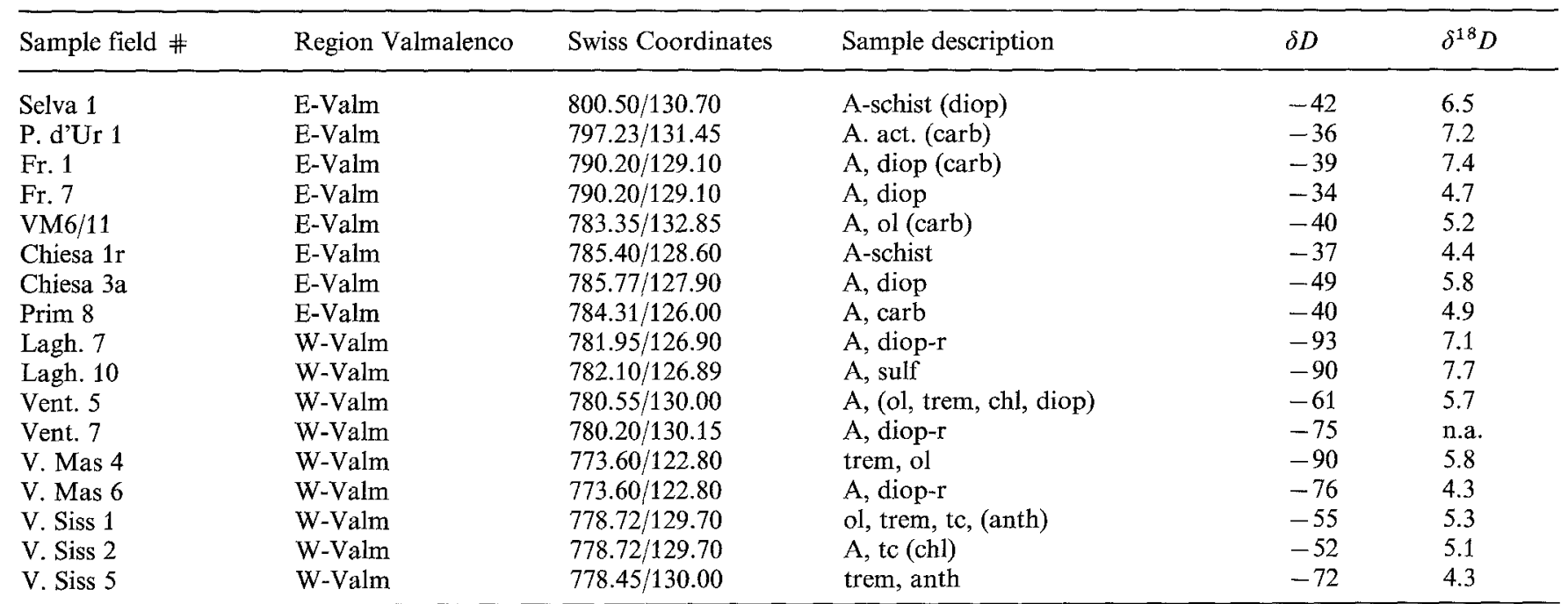

Description. $C$ : chrysotile; $L$ : lizardite; $A$ : antigorite; $B$ : bastite; cpx: clinopyroxene; diop: diopside; diop.-r: diopside relicts; ol: olivine; act: actinolite; chl: chlorite; trem: tremolite; $t c$ : talc; anth: anthophyllite; carb: carbonate; sulf: sulfide

$\delta^{18} O$ values are similar to those in the east Valmalenco but the $\delta D$ values are distinctly lower.

\section{Discussion}

\section{Water/rock ratios}

Water/rock ratios $(W / R)$ can be crudely calculated from the $\delta^{18} O$ value of the rock or dominant mineral in the rock using the equation of Taylor (1974).

$W / R=\left[\delta\left(R_{f}\right)-\delta\left(R_{i}\right)\right] /\left[A+\delta\left(W_{i}\right)-\delta\left(R_{f}\right)\right]$ where $\Delta=\delta(R)-\delta(W)$, and $R$ and $W$ are the atom percents of oxygen in the rock and water, respectively, and $i$ and $f$ refer to the initial and final conditions. The serpentinewater fractionation of Wenner and Taylor (1971) was used in the calculation:

$\Delta=0.6\left(10^{6} T^{-2}\right)-5.4$.

Many $\delta^{18} O$ values of the serpentine minerals are in the range of 6 to $8 \%$ and are thus not much different from those of the precursor minerals olivine and pyroxene (Taylor 1968). In these cases either the $W / R$ ratios were small 


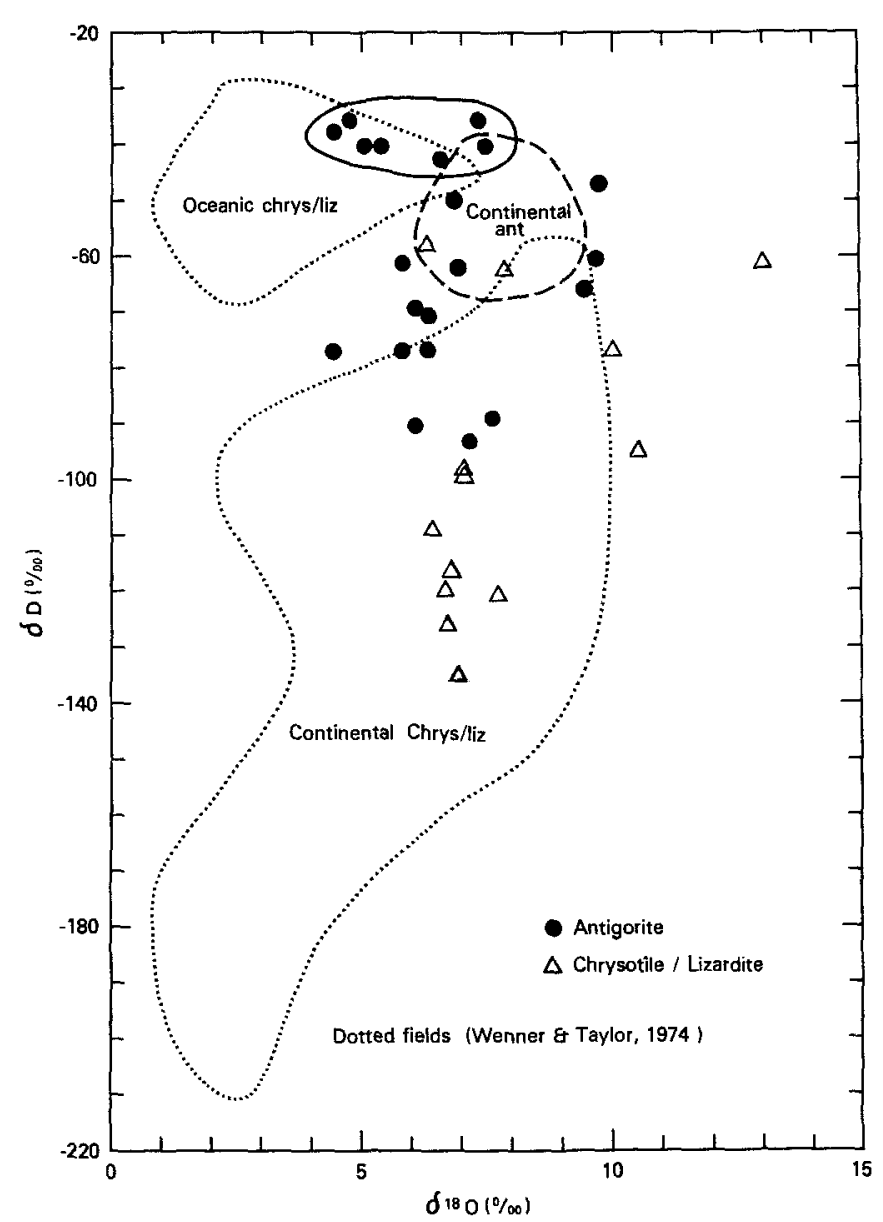

Fig. 2. $\delta^{18} O$ vs $\delta D$ of serpentine from the Arosa-Platta nappe and the Valmalenco

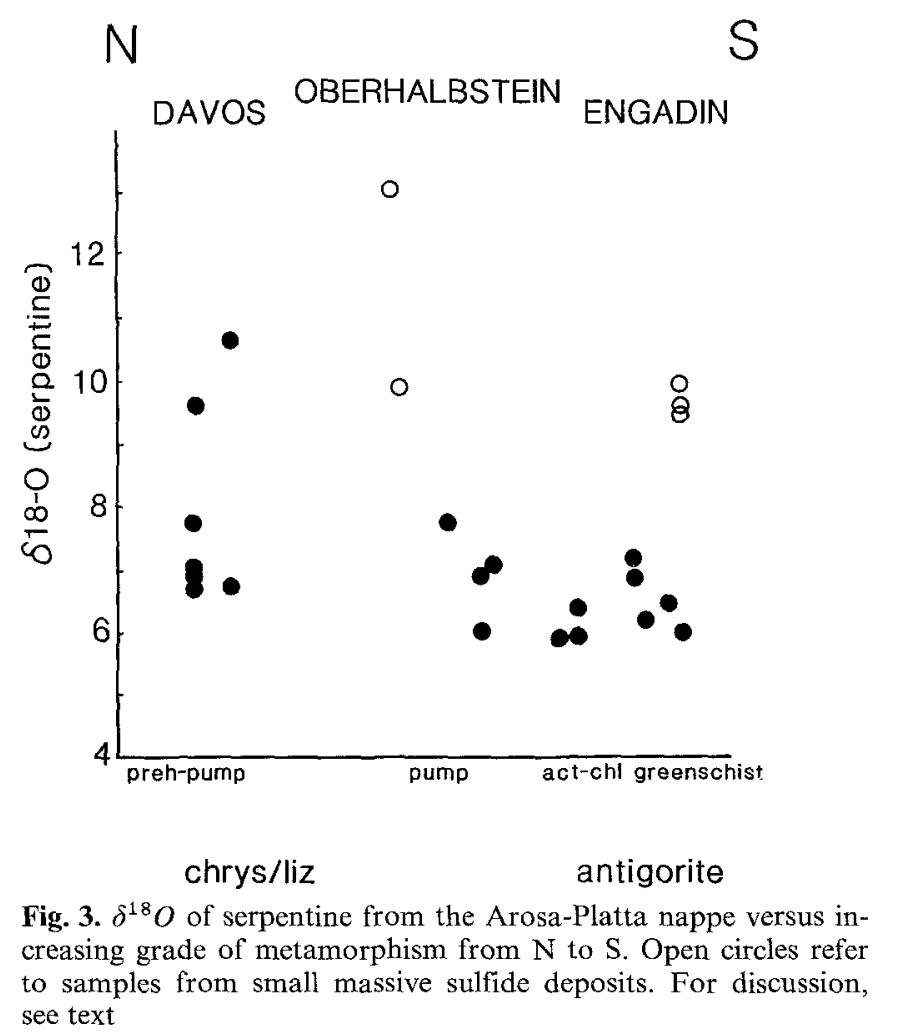

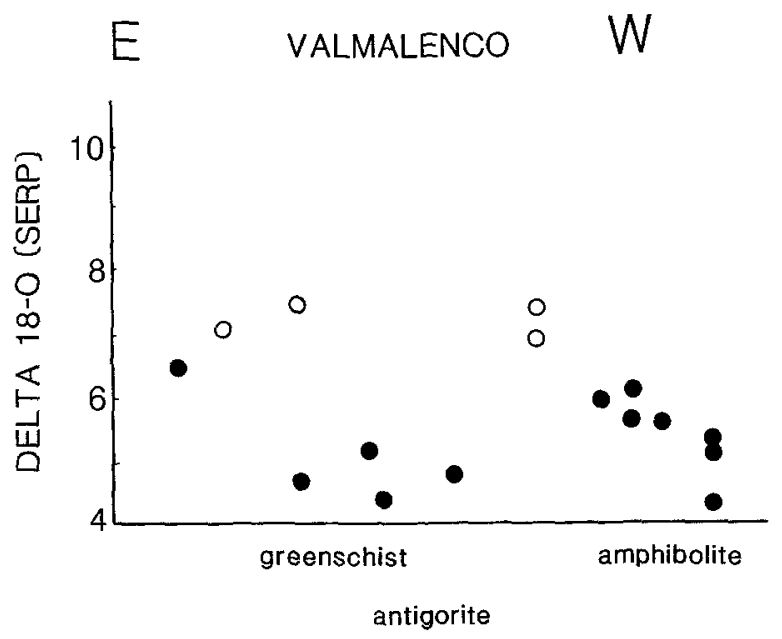

Fig. 4. $\delta^{18} O$ of antigorite from the Valmalenco area from $\mathrm{E}$ to W. Open circles refer to samples from small massive sulfide deposits. For discussion, see text

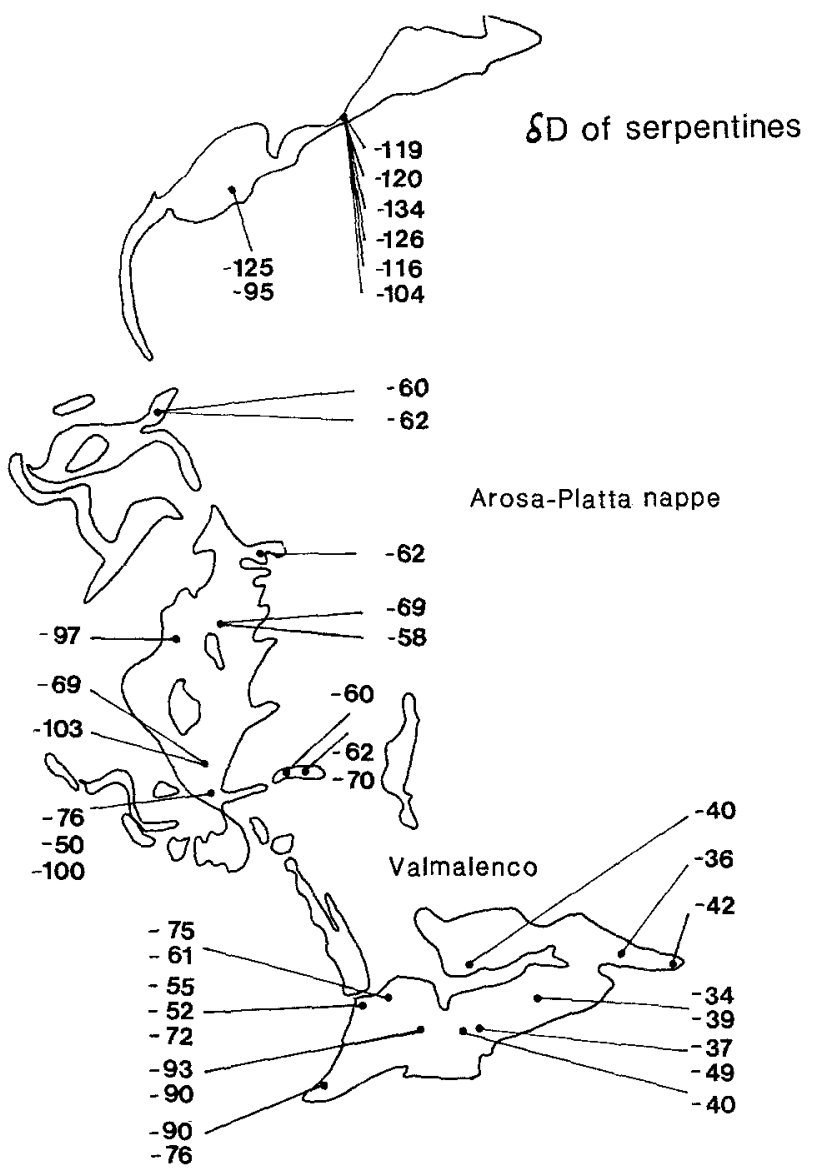

Fig. 5. $\delta D$ of serpentine from the Arosa-Platta nappe and the Valmalenco serpentines

or the metamorphic fluid was already close to oxygen isotope equilibrium with serpentine at the temperature of serpentinization. In the Valmalenco, especially in the east, $\delta\left(R_{f}\right)$ values of around $4 \%$ imply high $W / R$ ratios in the presence of fluids with a dominant component of ocean water for which $\delta\left(W_{i}\right)=0$. The high $\delta D$ and low $\delta^{18} O$ values of serpentines in the east Valmalenco provide evidence that this was the case. A $W / R$ ratio is 0.2 for a temperature of $400^{\circ} \mathrm{C}$ which is a reasonable assumption for the Valmalenco antigorite. 
In Fig. 3 the $\delta^{18} O$ values of serpentinites in the ArosaPlatta nappe are shown in relation to the geographical location of the sampling sites from $\mathrm{N}$ to $\mathrm{S}$, the direction of increasing grade of metamorphism. The open circles refer to analyses of serpentine (chrys/liz and ant) from sample localities with the small massive sulfide deposits which are usually located close to a tectonic boundary to the Austroalpine nappes. The increase in $\delta^{18} O$ from values presumably near $6.0 \%$ for the precursor minerals to values of about $10-13 \%$ suggests that either $W / R$ ratios were high and temperatures of serpentinization were low for these samples or that the $\delta^{18} \mathrm{O}$ values of the fluids were as high as about $10 \%$. Such high values are common for regional metamorphic fluids. Since most of the data are in the $6-8 \%$ range, samples with high $\delta^{18} O$ values are presumably very local. From the geological evidence of extensive serpentinization of these rocks and enhanced tectonization close to the nappe boundary, it would appear that $W / R$ ratios were indeed high in these cases.

The very high $\delta^{18} O$ value of $13.0 \%$ for sample OH1/9 from the Oberhalbstein (chrys/liz) is particularly noteworthy. Hitherto, values this high have been observed only for a few samples (deweylites) from the Troodos ophiolite, Cyprus by Margaritz and Taylor (1974) and a single sample from the Vourinos ophiolite, Greece by Wenner and Taylor (1973). The Oberhalbstein sample OH1/9 contains large bastites which Wenner and Taylor (1973) also noted are associated with higher ${ }^{18} \mathrm{O} /{ }^{16} \mathrm{O}$ ratios of samples from a given area. The relation between the presence of bastites and unusual ${ }^{18} \mathrm{O}$ enrichment is not understood. This sample also contains a minor portion of later serpentine vein material which might be responsible in part for the oxygen isotope composition. However, serpentine veins of different generations are common in metamorphosed serpentinites. Due to the extremly small size of these veins, they could not be separated for isotopic analyses.

With the exception of the samples just discussed, the $\delta^{18} O$ values of these serpentines, like those of chrys/liz from most areas of the world, are near those of the precursor minerals (Wenner and Taylor 1974). There is a general trend over a spread of about $2 \%$ to lower $\delta^{18} \mathrm{O}$ values with increasing grade of metamorphism. This trend is best explained by some combination of higher temperatures and lower $W / R$ ratios for the higher grade rocks. In any event, the $W / R$ ratios must be fairly low in the higher grade rocks for the $\delta^{18} O$ values to remain similar to those of the precursor olivine and pyroxene.

Figure 5 is a similar presentation of data in relation to geographical location of samples in the Valmalenco. In this case the sole serpentine mineral determined under the microscope is antigorite and the $\delta^{18} O$ values are presented from east (Pass d'Ur) to west (Val Ventina). Again the open circles (higher $\delta^{18} O$ values) are associated with rocks located close to a tectonic boundary, in this case to Pennine meta-sediments. Noteworthy is the uniformity of the low $\delta^{18} O$ values in the east and west Valmalenco despite remarkable variations of $\delta D$ values.

\section{The serpentinization process}

A general controversy concerns the question of whether stable isotope data of serpentines, once formed, preserve their isotopic composition during later geological events or whether isotopic exchange occurs such that the original composition is (completely) overprinted (Wenner and Taylor 1974; Sakai and Tsutsumi 1978; Sheppard 1980; Yui and Yeh 1986). Sakai and Tsutsumi (1978) and Sheppard (1980) concluded that a solution of the problem requires more experimental data on the kinetics of exchange and equilibrium factors. However, it is generally accepted that hydrogen isotope exchange reactions between minerals and water proceed with greater facility than oxygen isotope exchange reactions as shown for example by the experiments of O'Neil and Kharaka (1976). While this may not be a valid generalization, the west Valmalenco antigorites, discussed below, may provide a new example of post formational hydrogen exchange.

The Arosa-Platta nappe. The very low $\delta D$ values (to $-134 \%$ ) of all serpentinites from the Davos and Arosa region indicate that meteoric water was a significant if not the dominant component of the serpentinizing fluid in this region. In the Oberhalbstein the $\delta D$ values of all serpentines range from -97 to $-58 \%$ indicating that in this region serpentinization took place in the presence of not only meteoric water, but also of metamorphic fluids. However, it cannot be decided whether meteoric water was introduced exclusively during a late serpentinization event or whether serpentinization took place in the presence of a composite fluid, although a mineralogical connection between the degree of serpentinization and the grade of regional metamorphism has been outlined. A recrystallization of serpentine, i.e., the formation of later serpentine generations, very likely occurred in the presence of predominantly meteoric water; sample OSCF4 $(\delta D=-103 \%$ ) contains large quantities of a late serpentine generation occurring in veins. In the Oberengadin, where antigorite predominates, the $\delta D$ values range between -76 and $-47 \%$. The value of $-100 \%$ (sample LPP) again seems to correlate with high amounts of a young serpentine generation, in this case picrolitic varieties of chry/liz. It is particularly noteworthy that at the contact to the sediments and at the nappe boundary, where enhanced water circulation and high $W / R$ ratios may be expected, the $\delta D$ values indicate that the serpentinizing fluids were predominantly metamorphic water and that meteoric water played a subordinate role. The correlation between increasing intensity of serpentinization and the progressive metamorphism suggests an alteration process on the continent that was related to the regional metamorphism. However, because of the experimental problem mentioned above, whether or not an earlier serpentinization took place in the presence of ocean water cannot be unambignously determined.

The Valmalenco. In contrast to serpentines in the ArosaPlatta nappe where the interpretation of the isotopic data is rather straightforward, the Valmalenco serpentines are exceptional and more difficult to interpret. Typical $\delta D$ values of metamorphic minerals in the Alps are around $-70 \%$ and some minerals that exchanged with meteoric water have $\delta D$ values as low as $-160 \%$ (Frey et al. 1976; Hoernes and Friedrichsen 1978). High $\delta D$ values of up to $-34 \%$ in the east Valmalenco together with low $\delta^{18} \mathrm{O}$ values near $4.0 \%$ provide strong evidence for ocean water serpentinization if the data are interpreted in terms outlined by Wenner and Taylor $(1973,1974)$. In this case the possibility that serpentinization occurred in the presence of metamorphic and/or magmatic water can be excluded. The low 


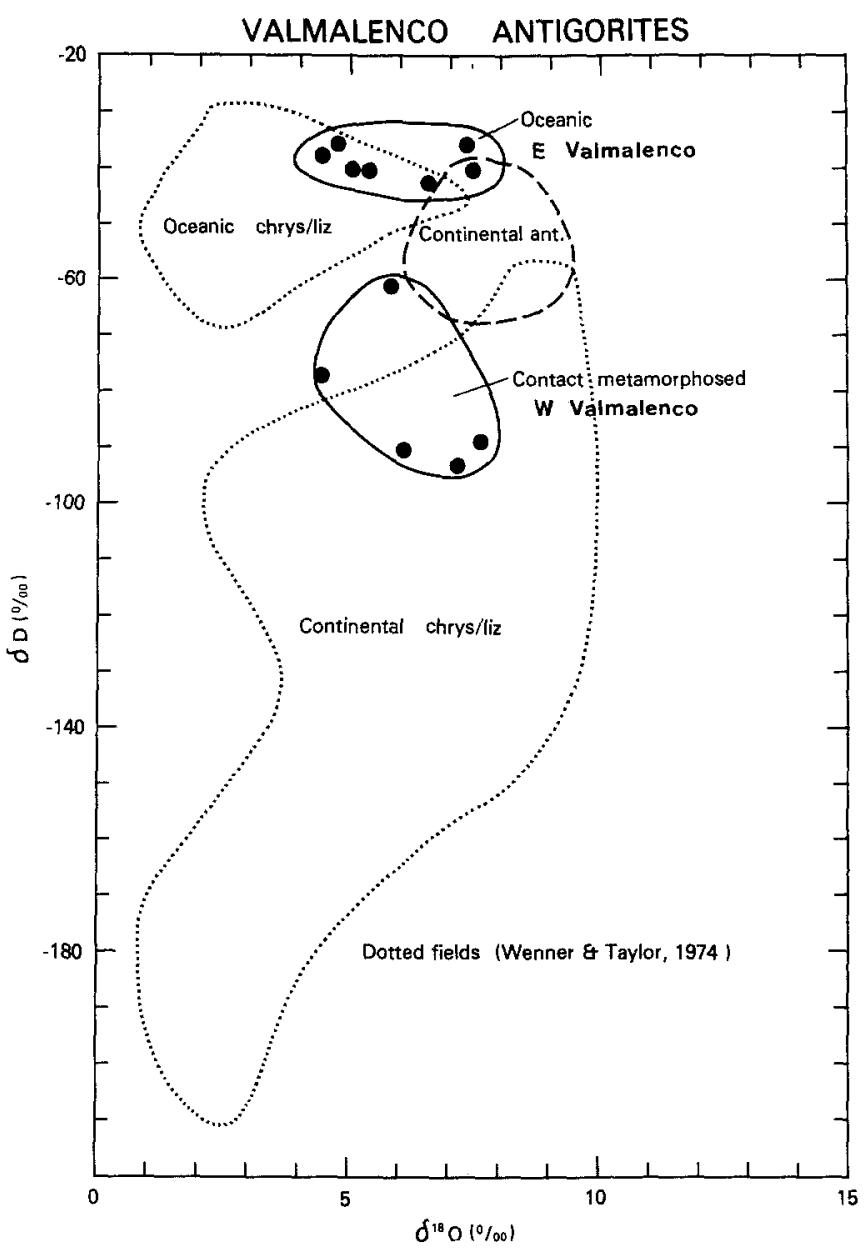

Fig. 6. Isotopic composition of the Valmalenco antigorite comparing groupings in the $\mathrm{E}$ and $\mathrm{W}$ Valmalenco

$\delta^{18} O$ values occur in both the east and west Valmalenco whereas $\delta D$ values in the west Valmalenco are much lower than in the east, at -93 to $-60 \%$ (Fig. 6). The boundary between east and west is probably NNW-SSE oriented and passes about $4 \mathrm{~km}$ west of Chiesa (corresponds to locality 19 in Fig. 1). If the isotopic data of the east Valmalenco are interpreted in terms of the serpentine-water fractionation of Sakai and Tsutsumi (1978), ocean water need not be necessarily the only fluid present during serpentiniation but an additional minor component of meteoric water is possible. However, since these authors restricted their investigation to hydrogen isotopes, the results must be considered carefully. The presence of several antigorite generations in the Valmalenco is reflected very likely in the span of data in the east Valmalenco. Any alternative, such as a serpentinization in the presence of fluids with a dominant component of other than seawater, or a later exchange of serpentine minerals with other fluids, faces the problem that low $\delta^{18} O$ values of less than $6 \%$ must be explained. Because of a preserved pre-alpine foliation the main serpentinization process should have occurred pre-orogenically, and must have been accompanied by tectonization. Alpine metamorphism probably caused recrystallization and formation of younger mineral generations. A serpentinization during regional metamorphism with trapped ocean water fluids as described for example for the Monte Rosa granite (Frey et al. 1976) or for micas in the Trois Seigneurs Massif, Pyrenees, (Wickam and Taylor, 1985) is very unlikely for peri- dotites. Two alternatives may be considered for the Valmalenco serpentinite:

(1) If the isotopic composition of serpentine minerals are retained during later geological events, serpentinization of the previous Valmalenco peridotite can be assumed to have occurred either, (a) retrograde, directly to antigorite for reasons which mainly concern the relatively high degree of mineral equilibration compared to the adjacent serpentinites of the Arosa-Platta nappe (Burkhard 1987), or, (b) prograde, from precursor chrys/liz, as suggested by Mellini et al. (1987). One may assume that the transformation to antigorite occurred pre-alpine, again because of the preserved pre-alpine foliation, and that the isotopic composition of the precursor chrys/liz were essentially retained. In case (a), the $\delta^{18} O-\delta D$ relation (Figs. 2 and 6 ) describes a new field for oceanic antigorite found on the continent; in case (b), the data field may belong to Wenner and Taylor's field for "oceanic chrys/liz".

(2) If the serpentine minerals undergo isotopic exchange with fluids during post-formational geologic events we may assume either low $W / R$ ratios during regional metamorphism which makes this case ultimately indistinguishable from (1), or, that the antigorite data are part of an extended field for "continental antigorite" in Wenner and Taylor's presentation which means a metamorphic-magmatic isotopic signature. Major difficulties regarding an explanation of the low $\delta^{18} O$ values were mentioned above.

Sample P. d'Ur 1 from the east Valmalenco (Pass d'Ur) comes from the tectonic boundary to Pennine meta-sediments (Margna nappe). This rock has the characteristic metasomatic mineral paragenesis of this locality and contains actinolite (tremolite), carbonate, some diopside and only small amounts of antigorite. Amphibole is the dominant hydrous phase and it has a high $\delta D$ value of $-36 \%$ like the antigorite from the east Valmalenco. Thus, the metasomatic event probably also took place in the presence of ocean water. There is every reason to assume that metasomatism and serpentinization took place concurrentiy in the presence of the same fluid. Consequently, peridotite and sediment were already in contact very early in their history, probably before orogeny and related regional metamorphism.

There are two possible explanations for the contrast between the high $\delta D$ values in the east and the low $\delta D$ values in the west Valmalenco: (1) the different isotopic compositions of serpentine are primary (2) an originally uniform serpentinite composition was altered in the west to the now lower $\delta D$ values by a later overprinting event related to the Bergell intrusion. Possibility (1) would separate the east from the west Valmalenco by a decisively different primary alteration history, in the east with oceanic water and in the west with metamorphic (+meteoric) water. This also implies a severely different geologic history. It is, however, remarkable that the unusually low $\delta^{18} O$ values, characteristic of oceanic serpentine, also occur in the west. There is so much oxygen in hydrous minerals relative to hydrogen that during incomplete exchange reactions with water the hydrogen isotope composition of the mineral can change substantially while the oxygen isotope ratio is effectively buffered and remains nearly the same. So, the oxygen isotope data of the Valmalenco provide strong evidence that the entire Valmalenco serpentinite was a homogeneous body of oceanic serpentinite body prior to the intrusion of the Bergell granodiorite. 
Table 3. Stable isotope compositions of carbonate occurrences in serpentinites of the Arosa-Platta nappe and the Valmalenco

\begin{tabular}{|c|c|c|c|c|c|}
\hline Sample field & Region & Swiss Coordinates & Sample description & $\begin{array}{l}\delta^{13} C \\
(\mathrm{PDB})\end{array}$ & $\begin{array}{l}\delta^{18} O \\
\text { (SMOW) }\end{array}$ \\
\hline Sch. B. 1 & Oberhalbstein Arosa-Platta & bolder, near Bivio & ophicarb., A, mt, sulf. & 1.22 & 12.44 \\
\hline Lungh 14 & Engadin Arosa-Platta & $771.00 / 142.42$ & A, cpx, felt-like, (carb) & 0.3 & 15.66 \\
\hline Grev. 6 & Engadin Arosa-Platta & $776.20 / 144.23$ & A, L, (carb) & 2.59 & 15.60 \\
\hline Selva 1 & East Valmalenco & $800.50 / 130.70$ & A-schist, (diop), carb & 2.47 & 15.17 \\
\hline P. d'Ur 1 & East Valmalenco & $797.23 / 131.45$ & A. act, (carb) & 1.11 & 13.07 \\
\hline Fr. 1 & East Valmalenco & $790.20 / 129.10$ & A, diop, (carb) & 2.76 & 14.85 \\
\hline Str. Fr. & East Valmalenco & $789.50 / 128.50$ & & 3.32 & 12.99 \\
\hline Prim 8 & East Valmalenco & $784.31 / 126.00$ & A, carb & -2.37 & 11.61 \\
\hline Prim 9 & East Valmalenco & $784.31 / 126.00$ & A, carb & 0.81 & 12.84 \\
\hline Prim 10 & East Valmalenco & $784.31 / 126.00$ & tc, carb & 0.46 & 13.46 \\
\hline Lagh 4 & West Valmalenco & $781.80 / 127.00$ & A, diop, (carb) & 1.31 & 13.86 \\
\hline V. Mas 6 & West Valmalenco & $773.60 / 122.80$ & A, diop-r & -2.37 & 10.31 \\
\hline
\end{tabular}

Description. Ophicarb.: ophicarbonate; $m t$ : magnetite; $L$ : lizardite; $A$ : antigorite; cpx: clinopyroxene; diop: diopside; diop.-r.: diopside relicts; ol: olivine; act: actinolite; $t c$ : talc; carb: carbonate; sulf: sulfide

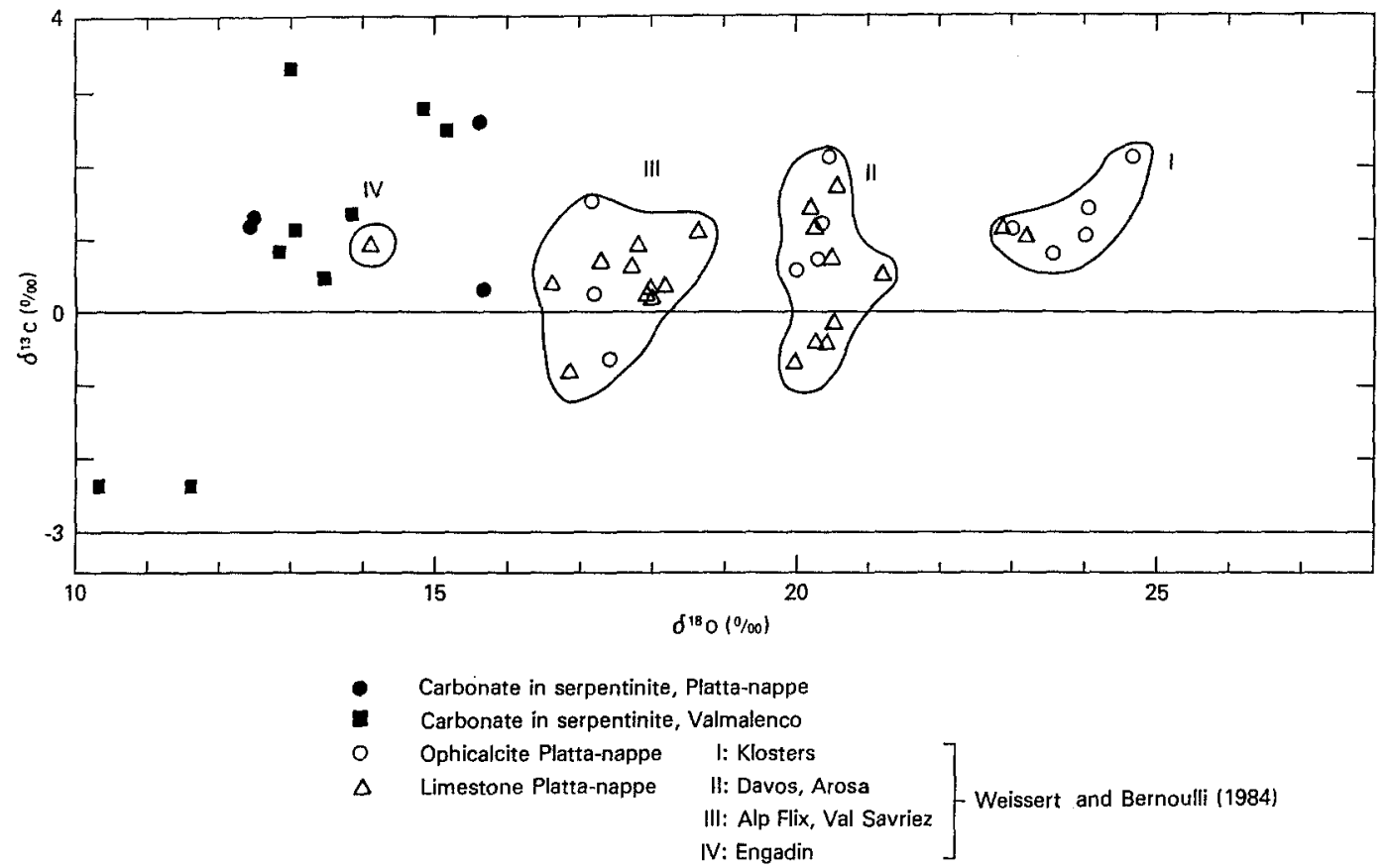

Fig. 7. $\delta^{18} O$ vs $\delta^{13} \mathrm{C}$ of tiny amounts of carbonate in serpentinite of the Arosa-Platta nappe and the Valmalenco compared to data of ophicalcite and limestone in Weissert and Bernoulli (1984)

The $\delta D$ value of a single sample of the Bergell granite is $-78 \%$. Any water released from this crystallizing magma would have had a $\delta D$ value that was higher than $-78 \%$ o because water vapor is richer in deuterium than water (-OH) in the melt (compare for example Taylor and Sheppard, 1986). The low $\delta D$ values of the intruded west Valmalenco serpentinites are very likely the result of an overprint by fluids related to the granitic intrusion and subsequent meteoric fluids. During the contact metamorphism of the west Valmalenco, water released in dehydration reactions of serpentine (antigorite + diopside $=$ forsterite + tremolite + water, and antigorite $=$ forsterite + talc + water, for example in Trommsdorff $1983 \mathrm{a}, \mathrm{b}$ ) should have been enriched in $D$ relative to its source leaving antigorite with lowered $D$ contents (Rumble 1982; Ikin and Harmon 1983). However, there is no obvious relation between $D / H$ ratios and the metamorphic mineral paragenesis, or the proximity to the Bergell intrusion.

These effects readily explain the retention of the original low $\delta^{18} O$ values and the lowering of $\delta D$ values in the west Valmalenco.

\section{Carbonates}

Although serpentinites were collected only outside ophicarbonate zones in both the Arosa-Platta nappe and the Valmalenco occurrences, occasionally tiny amounts of carbonate (calcite) are observed under the microscope. In favorable cases it was possible to analyze whole rock samples for the carbon and oxygen isotope composition of the carbonate with the standard $\mathrm{H}_{3} \mathrm{PO}_{4}$ method. The results of these analyses are given in Table 3 and presented in Fig. 7. 
The $\delta^{13} C$ values near zero $(0.3-2.6 \%$ PDB for the Oberhalbstein and Oberengadin; -3.3 to $-2.2 \%$ PDB for the Valmalenco) suggest a marine origin for all the carbon. Such carbonate was probably formed from fluids that derived $\mathrm{CO}_{2}$ from adjacent carbonate-bearing sediments and limestone. Calcium could have been derived from clinopyroxene or brought in with the fluids. The oxygen isotope ratios of these sediments correlate well with the increasing grade of metamorphism (Weissert and Bernoulli 1984). The $\delta^{18} O$ values of the tiny amounts of carbonate in the serpentinites $(12.4-15.6 \%$ in the Oberhalbstein and Oberengadin; $10.3-14.9 \%$ in the Valmalenco) unfortunately are not systematic and only roughly correlate with metamorphic grade. It was originally hoped that coexisting carbonate and serpentine could be used for oxygen isotope thermometry. Combining these results with those obtained from serpentine, one may conclude that the carbonates formed in the presence of metamorphic fluids (in the Arosa-Platta nappe) and ocean water (in the Valmalenco). This process either took place at various times, during and after the metamorphism (for example as tiny late vein fillings), or the carbonate oxygen did not completely equilibrate with the metamorphic fluid. Thus the inhomogeneous stable isotope compositions of the carbonates are not very informative.

\section{Conclusions}

Stable isotope compositions of serpentines from two adjacent serpentinized ultramafic occurrences from the ArosaPlatta nappe and the Valmalenco are different and correlate with geologic and mineralogic differences.

In the Arosa-Platta nappe the degree of serpentinization correlates with the grade of metamorphism. The hydrogen isotope compositions of serpentine indicate that meteoric water was a dominant component of the serpentinizing fluids in the lower grade serpentinites to the north whereas metamorphic waters (and in places also meteoric water) were dominant elsewhere. Also, at nearby nappe boundaries, serpentinization is related to the regional metamorphic event as indicated by the $\delta D$ values, but higher $\delta^{18} O$ values at these locations suggest that water/rock ratios were higher there.

High $\delta D$ values of near $-40 \%$ and $\delta^{18} O$ values as low as 4.0 in the east Valmalenco suggest that serpentinization of the precursor peridotite occurred predominantly in the presence of ocean water. In the west Valmalenco low $\delta^{18} O$ values are probably preserved from an original serpentinization in ocean water and the $\delta D$ values were lowered by incomplete exchange reactions with fluids that exsolved from the Bergell intrusions. During the evolution of these fluids a component of meteoric water was added. In all cases the isotopic ratios suggest a limited water/rock ratio.

For the first time continental antigorite with an ocean water isotopic signature has been identified. The high $\delta^{18} O$ value of $13.0 \%$ measured for a sample of chrys/liz is rare and provides additional important support for the concept of low-temperature serpentinization.

Because sufficient data on the rates of isotopic exchange between serpentine and water fractionation are not available, we do not know to what extent existing isotopic compositions reflect the original serpentinization event. It is possible that, during regional metamorphism in the ArosaPlatta nappe, recrystallization of serpentine occurred at suf- ficiently high water/rock ratios in fluids sufficiently far removed from hydrogen and/or oxygen isotope equilibrium and that the original isotopic composition was altered. We are invoking such a process to explain the isotopic relations in the west Valmalenco. However, high $\delta D$ values of serpentine preserved only in the east Valmalenco have to be interpreted dominantly as an ocean water serpentinization accompanied or followed by conditions which allowed a high degree of mineral equilibration. Different generations of minerals appear to be related to regional metamorphism. One may ask why occurrences with such high $\delta D$ values are not more common. In any case, the very different character of the adjacent Engadin region, mineralogically and isotopically, imply severe differences with respect to the geologic/tectonic evolution of the two areas in the alpine collision belt.

Acknowledgments. The "Studienstiftung des Deutschen Volkes" financed part of the present study which is a portion of the Ph.D. thesis of the first author and made possible a research year at the U.S. Geological Survey in Menlo Park. Lanny Adami and Matt Stairs are thanked for their aid in the isotopic analyses. The authors acknowledge Prof. A. Matthews's constructive suggestions and Prof. G.C. Amstutz's critical reading of various versions of the manuscript.

\section{References}

Barnes I, O'Neil JR (1969) The relationship between fluids in some fresh Alpine-type ultramafics and possible modern serpentinization, Western United States. Geol Soc Am Bull 80:1947-1960

Barnes I, O'Neill JR, Trescases JJ (1978) Present day serpentinization in New Caledonia, Oman and Yugoslavia. Geochim Cosmochim Acta 42:144-145

Bucher K, Pfeifer HR (1973) Metamorphose und Deformation der östlichen Malenco Ultramafite und deren Rahmengesteine, Prov. Sondro N-Italien. Schweiz Mineral Petrogr Mitt $53: 231-241$

Burkhard DJM (1987) Ore minerals and geochemistry in the serpentinites of the eastern Central Alps (Davos to the Val Malenco) compared to occurrences in the Klamath Mountains ( $\mathrm{Ca}$ lifornia and Oregon). Ph D Thesis, University of Heidelberg. Geowiss Abh 12, 345 p

Burkhard DJM, Amstutz GC (1988) Spinel-exsolution and the variations of chrome spinel alteration in serpentinites of the eastern Central Alps, Arosa-Platta nappe and the Valmalenco (Switzerland, Italy), (accepted for Mineralogy and Petrology)

DeCapitani L, Ferrario A, Montrasio A (1981) Metallogeny of the Val Malenco meta-ophiolitic complex, Central Alps. Ofioliti 6:87-100

Dietrich V (1967) Vulkanismus in den oberen penninischen Decken Graubündens. Geol Rundsch 57:246-264

Dietrich V (1969) Die Ophiolithe des Oberhalbsteins (Graubünden) und das Ophiolithmaterial der Ostschweizerischen Molasseablagerungen. Ein petrographischer Vergleich. Europäische Hochschulschriften, XVII, 1, $180 \mathrm{p}$

Dietrich V (1970) Die Stratigraphie der Platta-Decke. Eclog Geol Helv 63:631-671

Dietrich V (1972) Die sulfidischen Vererzungen in den Oberhalbsteiner Serpentiniten. Geol Schweiz Geotechn Serie 49, 128 p

Dietrich V (1979) Investigation of ophiolitic occurrences and ophiolitic detritus in the eastern Alps. Schweiz Mineral Petrogr Mitt 59:179-180

Dietrich V, Peters T (1971) Regionale Verteilung der Mg-Phyllosilikate in den Serpentiniten des Oberhalbsteins. Schweiz Mineral Petrogr Mitt 51:329-348

Frey M, Hunziker JC, O'Neill JR, Schwander HW (1976) Equilibrium-disequilibrium relations in the Monte Rosa granite, West- 
ern Alps. Petrological Rb-Sr and stable isotope data. Contrib Mineral Petrol 55:147-179

Gautschi A, Montrasio A (1978) Die andesitisch-basaltischen Gänge des Bergeller Ostrandes und ihre Beziehung zur Regional- und Kontaktmetamorphose. Schweiz Mineral Petrogr Mitt 58:329-343

Heaton THE, Sheppard SMF (1977) Hydrogen and oxygen isotope evidence for sea-water hydrothermal alteration and ore deposition, Troodos complex, Cyprus. Volcanic Processes in Ore Genesis Inst. Min Metall Geol Soc London, p 42-57

Hoernes S, Friederichsen HT (1978) Oxygen and hydrogen isotopic study of the polymetamorphic area of the Northern ÖtztalStubai Alps (Tirol). Contrib Mineral Petrol 67:305-315

Ikin NP, Harmon RS (1983) A stable isotope study of serpentinization and metamorphism in the Highland Border Suite, Scotland, UK Geochim Cosmochim Acta 47:153-167

Margaritz M, Taylor HP (1974) Oxygen and hydrogen isotopic studies of serpentinization in the Troodos Ophiolite Complex, Cyprus. Earth Planet Sci Lett 23:8-14

Mellini M, Trommsdorff V, Compagnoni R (1987) Antigorite polysomatism: behaviour during progressive metamorphism. Contrib Mineral Petrol 97:147-155

O'Neil JR, Kharaka YK (1976) Hydrogen and oxygen isotope exchange reactions between clay minerals and water. Geochim Cosmochim Acta 40:241-246

Peters T (1963) Mineralogie und Petrographie des Totalpserpentinits bei Davos. Schweiz Mineral Petrogr Mitt 43:531-685

Rumble III D (1982) Stable isotope fractionation during metamorphic devolatilization reactions. Characterization of metamorphism through mineral equilibria. Rev Mineral 10:327-353

Sakai H, Tsutsumi M (1978) D/H Fractionation factors between serpentine and water at $100^{\circ} \mathrm{C}$ to $500^{\circ} \mathrm{C}$ and 2000 bar water pressure, and the $\mathrm{D} / \mathrm{H}$ ratios of natural serpentines. Earth Planet Sci Lett 40:231-242

Sheppard SMF (1980) Isotopic evidence for the origins of water during metamorphic processes in oceanic crust and ophiolite complexes. Basic-Ultramafic association in orogenic belts. Intern Collq CRNS no 272, pp 135-147

Smith HS, O'Neil JR, Erlank AJ (1984) Oxygen isotope composition of minerals and rocks and chemical alteration patterns in pillow lavas from the Barberton Greenstone Belt, South Africa. In: A Kröner, GN Hanson, AM Goodwin (eds) Archean geochemistry. Springer, Berlin Heidelberg New York, Tokyo, p 115, 137

Stakes DS, O’Neil JR (1982) Mineralogy and stable isotope geochemistry of hydrothermally altered oceanic rocks. Earth Planet Sci Lett 57:285-304
Taylor HP Jr (1968) The oxygen isotope geochemistry of igneous rocks. Contrib Mineral Petrol 19:1-71

Taylor HP (1974) The application of oxygen and hydrogen isotope studies to problems of hydrothermal alteration and ore deposition. Econ Geol 69:843-883

Taylor HP, Sheppard SMF (1986) Igneous rocks: I. Processes of isotopic fractionation and isotopic systematics. In: JW Valley, HP Taylor, JR O'Neil (eds) Stable isotopes in high temperature geological processes. Rev Mineral 16:227-271

Trommsdorff V (1983) Metamorphose magnesiumreicher Gesteine, ein kritischer Vergleich von Natur, Experiment und thermodynamischer Datenbasis. Fortschr Mineral 61:283-308

Trommsdorff V, Dietrich V (1980) Alpine metamorphism in a cross-section between the Rhine and Valtellina valleys (Switzerland, Italy) 317-334. Geology of Switzerland, Part B, geological excursions. Schweiz Geol Kommission, Wepf, Basel New York

Trommsdorff V, Evans BW (1972) Progressive metamorphism of antigorite schists in the Bergell tonalite aureole (Italy). Am J Sci 272:423-437

Trommsdorff V, Evans BW (1977) Antigorite-ophicarbonate contact metamorphism in Valmalenco. Contrib Mineral Petrol $62: 301-312$

Weissert H, Bernoulli D (1984) Oxygen isotope composition of calcite in Alpine ophicarbonates, a hydrothermal or Alpine metamorphic signal? Eclog Geol Helv 77:29-43

Wenner DB, Taylor HPJ (1971) Temperature of serpentinization of ultramafic rocks based on ${ }^{18} \mathrm{O} /{ }^{16} \mathrm{O}$ fractionation between coexisting serpentine and magnetite. Contrib Mineral Petrol 32:165-185

Wenner DB, Taylor HP (1973) Oxygen and hydrogen isotopic studies of the serpentinization of the ultramafic rocks in oceanic environments and continental ophiolitic complexes. Am J Sci 273:207-239

Wenner DB, Taylor HP (1974) D/H and ${ }^{18} \mathrm{O} /{ }^{16} \mathrm{O}$ studies of serpentinization of ultramafic rocks. Geochim Cosmochim Acta 38:1255-1286

Wickham ST, Taylor H (1985) Stable isotopic evidence for large scale seawater infiltration in a regional metamorphic terrane; the Trois Seigneure Massif. Contrib Mineral Petrol 91:122-137

Yui TF, Yeh HW (1986) H- and O-Isotope geochemistry of serpentinite and serpentinization. Bull Inst Eearth Sci Acad Sin $6: 197-209$

Received November 23, 1987 / Accepted April 13, 1988

Editorial responsibility: J. Hoefs 